\title{
Effect of Carvedilol on Secondary Damage in Experimental Spinal Cord Injury in Rats
}

\section{Ratlarda Deneysel Omurilik Travmasında Karvedilol'ün Ikincil Hasara Etkisi}

\author{
Yasar KARATAS ${ }^{1}$, Sahika Liva CENGIZ ${ }^{2}$, Hasan ESEN ${ }^{3}$, Aysun TOKER ${ }^{4}$, Cigdem SAVAS $^{5}$ \\ ${ }^{1}$ Kahta State Hospital, Department of Neurosurgery, Adiyaman, Turkey \\ ${ }_{2}^{2}$ Serik State Hospital, Department of Neurosurgery, Antalya, Turkey \\ ${ }^{3}$ Necmettin Erbakan University, Meram School of Medicine, Department of Pathology, Konya, Turkey \\ ${ }^{4}$ Necmettin Erbakan University, Meram School of Medicine, Department of Biochemistry, Konya, Turkey \\ ${ }_{5}^{5}$ ecmettin Erbakan University, Meram School of Medicine, Department of Public Health, Konya, Turkey
}

Corresponding Author: Yasar KARATAS / E-mail: yasarkrts@gmail.com

\begin{abstract}
AIM: Previous studies have shown that carvedilol has a neuroprotective effect in animal models of brain ischemia and brain oxidative damage in vitro. This study was perfomed to investigate the effect of carvedilol on the secondary damage in experimental spinal cord injury (SCI).

MATERIAL and METHODS: Twenty-four Wistar albino rats were divided into three groups. Group 1 underwent laminectomy alone. Group 2 underwent laminectomy followed by $\mathrm{SCl}$ and received carvedilol. Group 3 underwent laminectomy followed by $\mathrm{SCl}$ and received no medication. The neurological functions were assessed by Tarlov's motor scale at the first and 24th hours. Oxidative stress status was assessed by MDA, SOD, MPO, GSH activities. A TUNEL-based apoptosis kit was used for evaluating apoptosis in the spinal cord samples and hematoxylinand eosin-stained specimens were used for light microscopic examination.
\end{abstract}

RESULTS: Carvedilol reduced apoptosis and regulated oxidant and antioxidant status by increasing SOD and GSH levels and reducing MPO and MDA levels in the spinal tissue homogenate. Neurological examination of rats revealed statistically significant improvement 24 hours after the trauma.

CONCLUSION: Carvedilol has a statistically significant therapeutic effect, especially on functional recovery, and we found that carvedilol reduced secondary damage by inhibiting apoptosis and regulating the oxidant and antioxidant status.

KEYWORDS: Carvedilol, Spinal trauma, Apoptosis, Secondary damage

öz

AMAÇ: Beyinde oksidatif hasar ve iskemi ile ilgili daha önce yapılan in vitro hayvan modeli çalışmalarında karvedilolün nöron koruyucu etkilerinin olduğu gösterildi. Çalışmada karvedilolün deneysel spinal travma modelinde ikincil hasar üzerine olan etkileri araştırıldı.

YÖNTEM ve GEREÇLER: 24 adet Wistar albino tipi sıçan üç gruba ayrıldı. Spinal kord yaralanması ağırlık düşürme modeli ile gerçekleştirildi. Birinci gruba sadece laminektomi uygulandı. İkinci gruba laminektomi yapılarak spinal kord yaralanması oluşturuldu ve karvedilol verildi. Üçüncü gruba laminektomi yapılıp spinal kord yaralanması oluşturuldu ve herhangi bir medikasyon uygulanmadı. Tüm gruplarda deneklerin birinci ve 24. saatlerde Tarlov motor skorlaması ile nörolojik muayeneleri kaydedildi. Oksidatif stres ölçümü için MDA (malonildialdehit), SOD (süperoksit dismutaz), MPO (myeloperoksidaz) ve GSH (glutatyon) aktiviteleri kullanıldı. Apoptozis düzeyini belirlemek için TUNEL kiti ve ışık mikroskobi bulguları için hematoksilen eozin boyası kullanıldı.

BULGULAR: Karvedilol apoptozis düzeyini azalttı ve SOD ile GSH düzeyini artırıp MPO ve MDA düzeylerini azaltarak oksidasyon ve antioksidasyon olaylarını düzenledi.

SONUÇ: Karvedilol özellikle fonksiyonel iyileşme üzerine istatistiksel olarak olumlu etki oluşturdu ve apoptozisi azaltıcı ve oksidasyonantioksidasyon olaylarını olumlu yönde düzenleyici etki gösterdi.

ANAHTAR SÖZCÜKLER: Karvedilol, Spinal travma, Apoptozis, İkincil hasar

\section{INTRODUCTION}

Spinal cord injury $(\mathrm{SCl})$ is the most destructive neuropathologic condition with neurological deficits and secondary complications (15). SCl occurs in two stages as primary and secondary injury. Mechanical destruction of nerve axons by the primary injury causes the induction of some biochemical and cellular cascades. Secondary injury starts in the first few minutes and continues for several weeks following the injury (7). Oxidative stress, inflammation, increased release of excitatory amino acids, lipid peroxidation, ion dysregulation and apoptosis are responsible for the secondary damage (8). Free radicals damage various cellular components, including proteins, lipids, and deoxyribonucleic acid (DNA). The central nervous system is highly vulnerable to free radical 
damage because of its high lipid content (12). Free radicals and inflammation lead to apoptosis and are responsible for neuronal and glial cell damage, as well as destruction of the cell membrane (8). Carvedilol, which is used for hypertension and congestive heart failure, is an adrenoceptor antagonist. It also behaves as a neuroprotective agent. $(9,17)$. This effect has been attributed to the free radical scavenging of carvedilol (10). Carvedilol has also been shown to possess neuroprotective effects in several models of transient focal stroke (11). In vitro studies showed that carvedilol inhibited superoxide anion release from activated neutrophils and lipid peroxidation. In addition, carvedilol protected cultured endothelial cells against oxygen-radical-induced cell injury $(18,19)$. However, the effects of carvedilol have not yet been reported in traumatic SCl. In the present study, we aimed to investigate the effects of carvedilol on oxidative damage, neuron cell apoptosis and neurological dysfunction in a rat model of traumatic $\mathrm{SCl}$.

\section{MATERIAL and METHODS}

\section{Animals}

Twenty-four Wistar albino rats weighing 250-300 g were housed in an air-conditioned room with 12-h light and dark cycles and relative humidity was kept constant. They were given free access to food and water. All experimental protocols were approved by the Necmettin Erbakan University Experimental Medicine Research and Application Center Experimental Animal Ethics Committee. Rats were divided into three groups of eight rats. Group 1 underwent laminectomy alone. Group 2 underwent laminectomy followed by $\mathrm{SCl}$ and received carvedilol. Group 3 underwent laminectomy followed by $\mathrm{SCl}$ and received no medication

\section{Induction of Spinal Cord Injury}

The animals were anesthetized by an intraperitoneal injection of $10 \mathrm{mg} / \mathrm{kg}$ xylazine (Rompun, Bayer Turk Kimya Sanayi Limited Sirketi, İstanbul, Turkey) and $50 \mathrm{mg} / \mathrm{kg}$ ketamine hydrochloride (Ketalar, Pfizer Ilacları Limited Sirketi, İstanbul, Turkey). Rats were positioned in the prone position. The surgical procedure was performed under sterile conditions.

Three level laminectomy was performed after the T6-10 midline skin incision and paravertebral muscle dissection. The dura was left intact. After visualization of the spinal cord, $\mathrm{SCl}$ was produced by using the weight drop technique. The animals were subjected to a $50 \mathrm{~g} / \mathrm{cm}$ impact to the surface of the spinal cord. The weight was a stainless steel rod with a rounded surface ( $3 \mathrm{~mm}$ in diameter and weighing $10 \mathrm{~g}$ ), which was dropped through a 5 -cm-long guide tube positioned perpendicular to the center of the spinal cord. After SCl, the incision was closed.

\section{Neurological Examination}

The neurological examination scores were assessed using Tarlov's scoring system(14). The animals were followed up for $24 \mathrm{~h}$ after the surgery and neurological assessment was carried out at the first and twenty-fourth hours. Neurological scores were assessed as follows: 0; Paraplegic, 1; Perceptible movement, 2; Some functional movement, 3; Hind limb movement and can support body weight, 4; Normal function.

\section{Measurement of Tissue Myeloperoxidase (MPO) Activity}

Activity of the neutrophil-specific MPO was measured by slight modifications. The spinal cord segments were homogenized with $50 \mathrm{mmol} / \mathrm{L}$ potassium phosphate buffer (pH: 6) on ice and the homogenates were centrifuged at $13.000 \mathrm{~g}$ for 20 minutes. The supernatant MPO activity was determined in $0.6 \mathrm{~mL}$ of $0.1 \mathrm{M}$ phosphate buffer (pH 6.0) containing o-dianesidine dihydrochloride $(0.167 \mathrm{mg} / \mathrm{mL})$ and hydrogen peroxide $(0.0005 \%)$. One unit of MPO activity was defined using MPO as a standard. The absorbance at $460 \mathrm{~nm}$ was monitored with spectrophotometer and calculated using a standard curve prepared for purified MPO. Specific activity is given as units per $\mathrm{g}$ of protein.

\section{Measurement of Tissue Glutathione (GSH) Levels}

The glutathione (reduced and oxidized form) content of tissues was determined using the assay kits from the Cayman Chemical Company (Ann Arbor, MI, USA) and the method of Elman (4). Glutathione peroxidase (GSH) is reacted with 5,5-dithiobis-2-nitrobenzoic acid resulting in the formation of a product which has absorbance at $410 \mathrm{~nm}$. Results were expressed as micromole per gram tissue $(\mathrm{mmol} / \mathrm{g})$.

\section{Superoxide Dismutase (SOD) Assay}

SOD activity was determined as described by Sun et al. (13). This method depends on the inhibition of nitroblue tetrazolium (NBT) reduction by xanthine-xanthine oxidase used as a superoxide generator. One unit of SOD activity was expressed as the amount of enzyme that causes $50 \%$ inhibition of the rate of NBT reduction. SOD activity was designated as units for $\mathrm{mg} /$ protein of spinal tissue.

\section{Measurement of Tissue Malondialdehyde (MDA) Levels}

MDA levels of the samples were measured by Draper and Hadley's method (3) based on thiobarbituric acid (TBA) reactivity. MDA, an end-product of fatty acid peroxidation, reacts with TBA to form a coloured complex that has maximum absorbance at $532 \mathrm{~nm}$. MDA activity was designated as unit for micromole per gram tissue $(\mathrm{mmol} / \mathrm{g})$.

\section{Histopathological Analysis}

Spinal cord samples were fixed in $10 \%$ paraformaldehyde and prepared with the Autotechnicon and then embedded in paraffin. Slices $(5 \mathrm{~mm}$ ) were obtained with a microtome and stained with hematoxylin and eosin. Hematoxylin and eosinstained specimens were examined under a Nikon Eclipse E400 light microscope (Nikon Instruments Inc, Melville, NY, USA). For detecting apoptosis in samples, a TUNEL (terminal deoxynucleotidyl transferase dUTP nick end labeling)-based apoptosis kit (Fragel DNA fragmentation kit, Calbiochem, Darmstadt, Germany) was used. In this method, 4-micron thick sections cut from paraffin blocks were first deparaffinized and rehydrated. They were permeabilized with proteinase $\mathrm{K}$ and endogenous peroxidase inactivated by $10 \% \mathrm{H} 2 \mathrm{O} 2$. For DNA 
labeling, Tdt labeling reaction mix and Tdt enzyme mixture were used. For detection of the reaction, DAB solution in $\mathrm{H}_{2} \mathrm{O}_{2}$ /urea mixture was used. Methyl green (3\%) was used for counter staining. Samples were then dehydrated and mounted with xylene. Terminal deoxynucleotidyl transferase dUTP nick end labeling-positive brown-stained cells were accepted as apoptotic in concordance with the positive control supplied by the manufacturer.

\section{Statistical Analysis}

For statistical evaluation, we used the software package SPSS 15.0. Statistical comparisons between groups were tested with the Kruskal-Wallis test, and the Mann-Whitney $U$ test was used for dual comparison. $p<0.05$ was considered statistically significant. The results are given as the mean \pm standard deviation of the mean (SD).

\section{RESULTS}

\section{Biochemical Assessment}

Figure 1 shows the mean levels of MPO in all groups. MPO activity, which is accepted as a determinant of neutrophil infiltration, was lower in the spinal cord tissues of rats that received carvedilol than in the trauma group. MPO levels were $1.67 \pm 0.84$ in the laminectomy alone group, $2.55 \pm 0.70$ in the carvedilol treatment group and $4.36 \pm 3.27$ in the trauma group. Carvedilol decreased MPO levels but this was not statistically significant ( $p>0.05)$.

Figure 2 shows the mean levels of MDA in all groups. MDA levels, an indicator of lipid peroxidation, were higher in the trauma group and lower in the carvedilol group. MDA levels were $2.49 \pm 1.58$ in the laminectomy alone group, $2.57 \pm 1.85$ in the carvedilol treatment group and $2.95 \pm 1.94$ in the trauma group. Carvedilol decreased MDA levels but this was not statistically significant ( $p>0.05)$.

Figure $3 \mathrm{~A}$ and $3 \mathrm{~B}$ shows the mean levels of GSH and SOD in all groups. GSH and SOD levels, which are the important antioxidant enzymes, were higher in the carvedilol treatment group than the trauma group. Comparisons between the carvedilol treatment group and trauma group showed no statistically difference $(p>0.05)$.

GSH levels were $1249.25 \pm 227.88$ in the laminectomy alone group, $1330.23 \pm 491.97$ in the carvedilol treatment group and $1190.43 \pm 255.77$ in the trauma group.

SOD levels were $845.46 \pm 362.46$ in the laminectomy alone group, $883.77 \pm 332.15$ in the carvedilol treatment group and $522.88 \pm 389.86$ in the trauma group.

\section{Neurological Assessment}

Figure 4 shows the mean levels of neurological examination in all groups. For each group, neurological examinations were performed at the first and 24th hours. The functional recovery was better in the carvedilol treatment group than the trauma group. Neurological examination showed recovery especially in the 24th hour and this was statistically significant $(p<0.05)$.

\section{Histopathological Assessment}

Photomicrographs show the degenerated glial cells with the yellow arrows and degenerated neurons with black arrows (hematoxylin eosin staining) in Figure 5: A) Laminectomy group, B) Trauma group, C) Carvedilol treatment group. Photomicrographs show apoptotic cells with black arrows (TUNEL staining) in Figure 5: D) Laminectomy group, E) Trauma group, F) Carvedilol treatment group.

Table I shows the histopathological analysis in all groups. The highest apoptosis values were in the trauma group. Carvedilol reduced apoptosis in the white and gray matter but there was no statistically significant difference between the trauma and carvedilol treatment groups ( $p>0.05)$.

The highest number of neurons and glial cells were in the laminectomy alone group. The neuron and glial cell counts

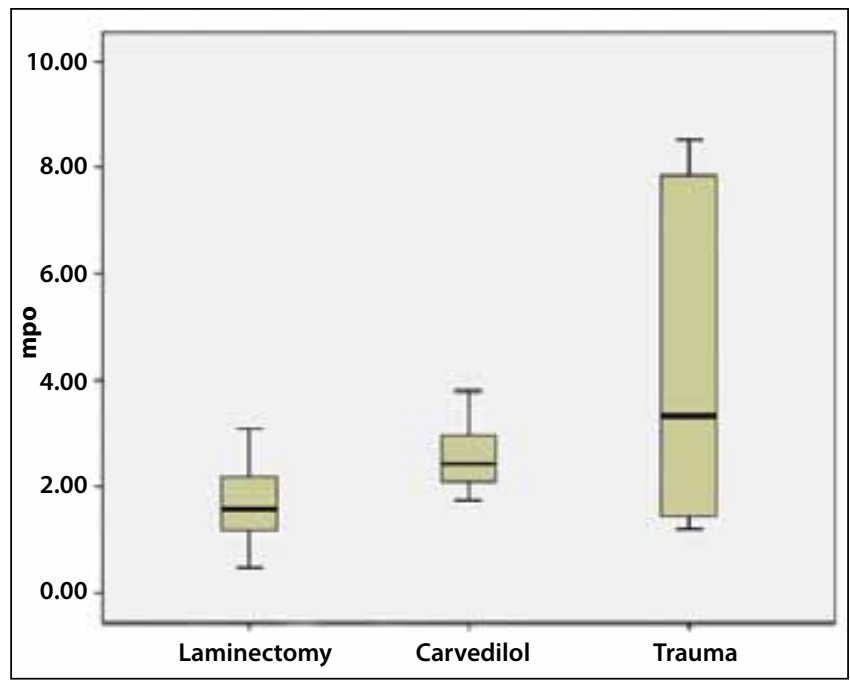

Figure 1: Graphic showing the mean values of MPO levels as $\mathrm{u} / \mathrm{g}$ protein.

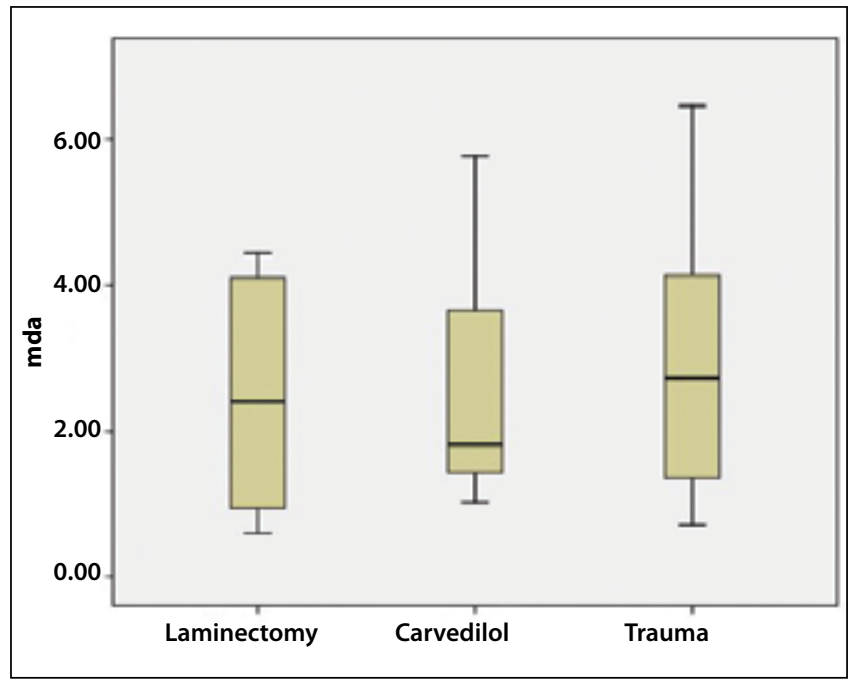

Figure 2: Graphic showing the mean values of MDA levels as micromol/g protein. 

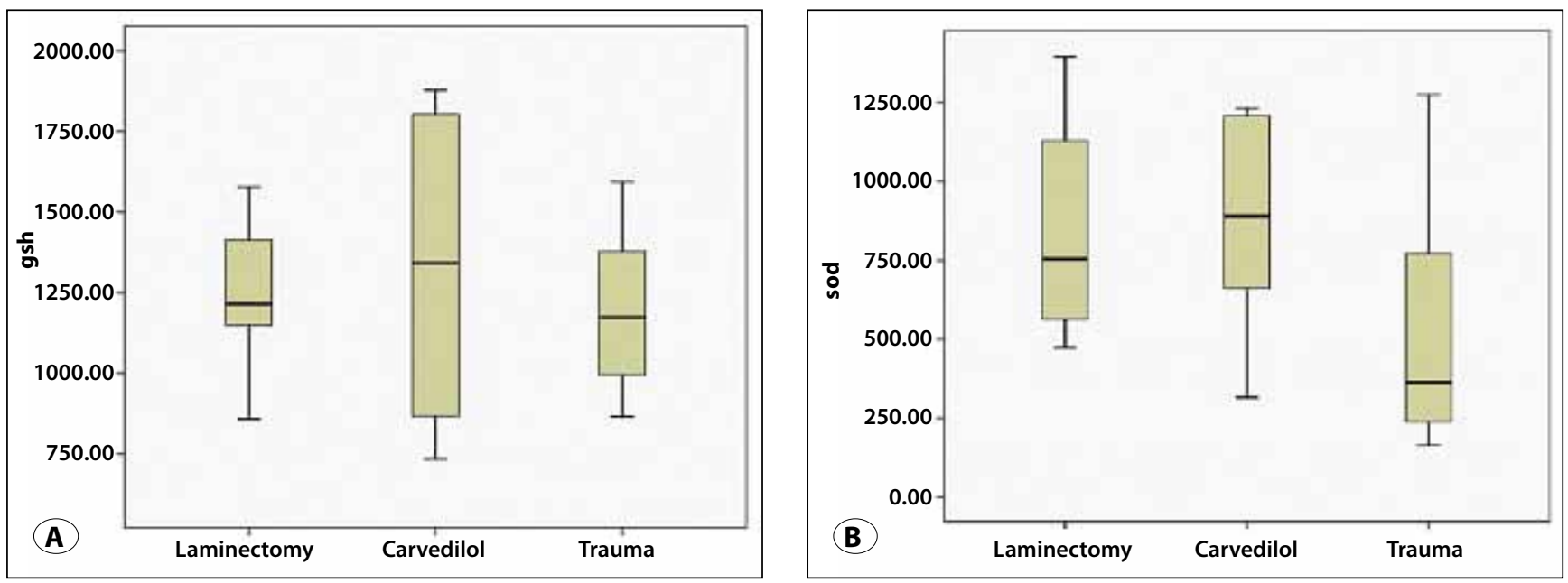

Figure 3A, B: Graphics showing the mean values of SOD as $\mathrm{u} / \mathrm{g}$ protein and GSH levels as micromol/g protein.

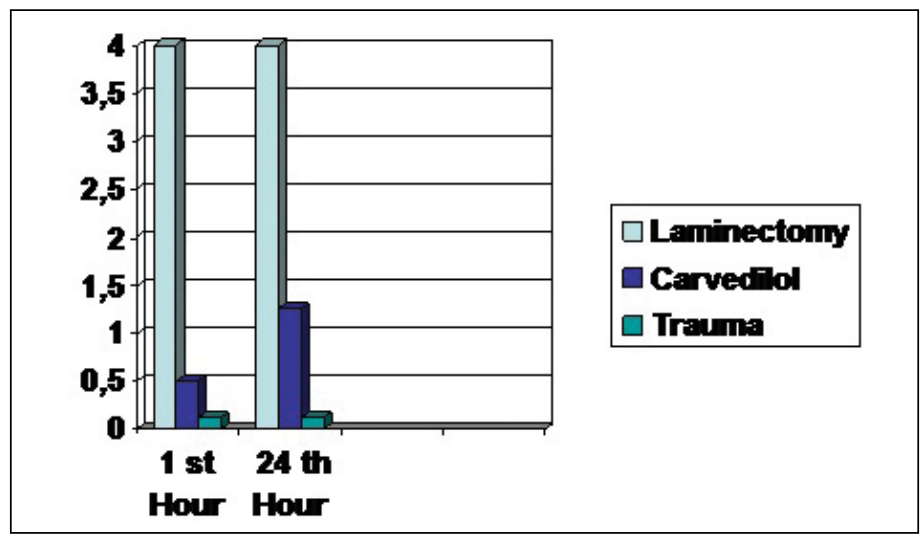

Figure 4: Graphics showing the mean levels of neurological examination in all groups.
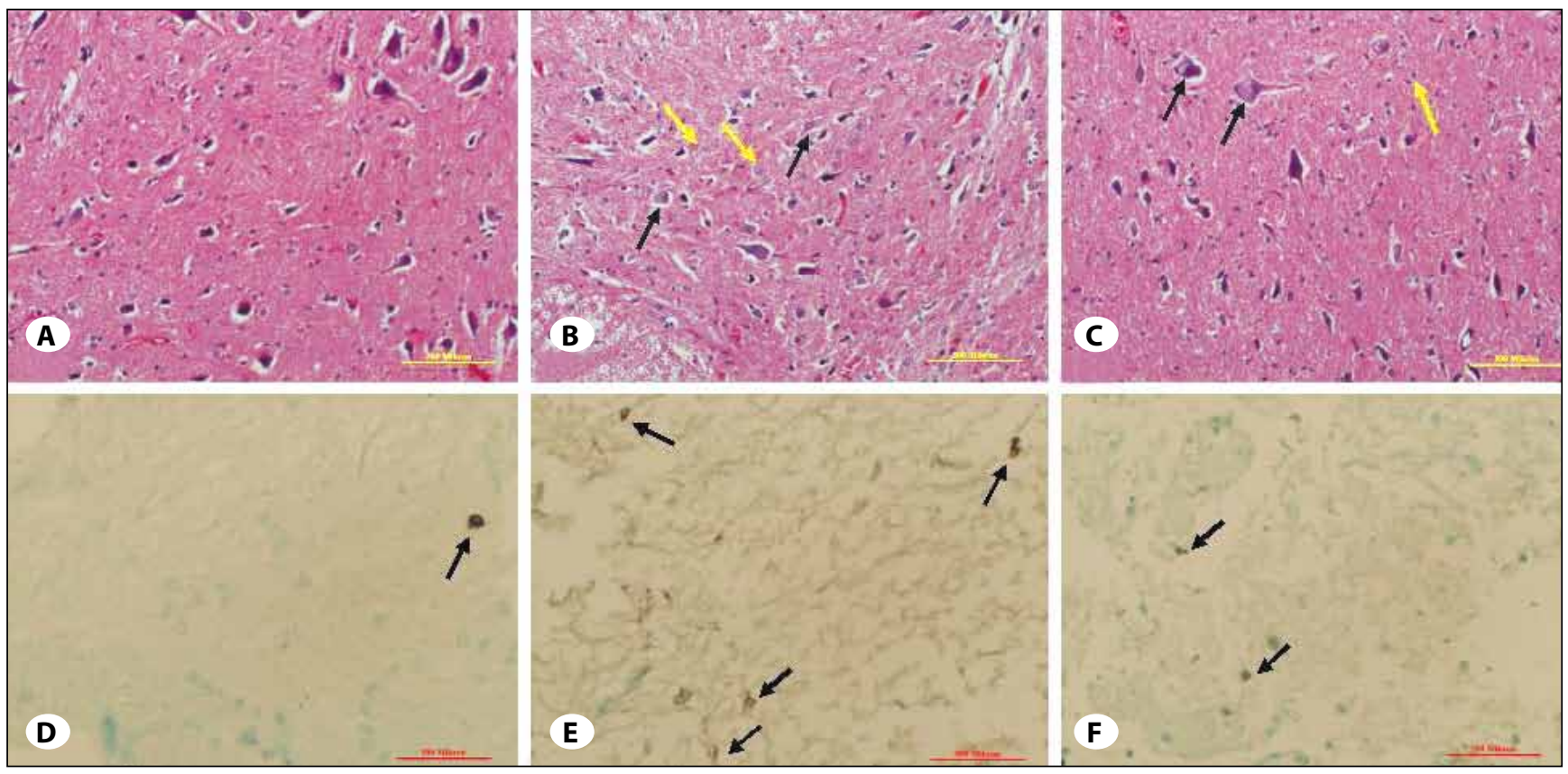

Figure 5: Photomicrographs showing degenerated glial cells with the yellow arrows and degenerated neurons with the black arrows (hematoxylin-eosin staining). A) Laminectomy group, B) Trauma group, C) Carvedilol treatment group. Photomicrographs showing apoptotic cells with the black arrows ( TUNEL staining). D) Laminectomy group, E) Trauma group, F) Carvedilol treatment group. 
Table I: Table Showing the Histopathological Analysis In all Groups

\begin{tabular}{|l|c|c|c|c|c|c|} 
& $\begin{array}{c}\text { Apoptosis } \\
\text { in the white } \\
\text { matter }\end{array}$ & $\begin{array}{c}\text { Apoptosis in the } \\
\text { gray matter }\end{array}$ & $\begin{array}{c}\text { Number of } \\
\text { neuron }\end{array}$ & $\begin{array}{c}\text { Number of } \\
\text { degenerated } \\
\text { neuron }\end{array}$ & $\begin{array}{c}\text { Number of } \\
\text { Number of } \\
\text { glial cells } \\
\text { değenerated } \\
\text { glial cells }\end{array}$ \\
\hline Laminectomy & $0.62500 \pm, 2$ & $0.6250 \pm 0.2$ & $21.8750 \pm, 4$ & $1.0000 \pm 0.2$ & $21,2500 \pm 3.8$ & $0.7500 \pm 0.8$ \\
\hline Carvedilol & $4.5000 \pm 0.8$ & $3.8750 \pm 0.5$ & $18.75001 \pm 0$ & $2.00000 \pm, 2$ & $18.25002 \pm, 4$ & $2.25000 \pm 0.7$ \\
\hline Trauma & $7.3750 \pm 0.8$ & $5.8750 \pm 0.4$ & $14.6250 \pm 0.8$ & $3.25000 \pm, 3$ & $14.6250 \pm 2.6$ & $3.7500 \pm 1.4$
\end{tabular}

were higher in the carvedilol treatment group than the trauma group but these differences were not statistically significant $(p>0.05)$.

The lowest number of degenerated neurons and glial cells were in the laminectomy alone group. Degenerated neuron and glial cell counts were lower in the carvedilol treatment group than the trauma group but these differences were not statistically significant $(p>0.05)$.

\section{DISCUSSION}

There is no still potent treatment of secondary damage after traumatic spinal cord injury. We know that the most important pathophysiological mechanisms of neuronal degeneration after $\mathrm{SCl}$ are free radical-induced oxidative damage, lipid peroxidation and apoptotic cell death (6). The nervous system is quite sensitive to free radical damage because of its high oxygen content and limited antioxidant enzyme activity. Lipids are the biological molecules most sensitive to oxidative damage. The nervous system is therefore very sensitive to lipid peroxidation (2). It has been shown that carvedilol scavenges free radicals and inhibits lipid peroxidation in swine ventricular membranes and rat brain homogenates (16). There is no previous study that has investigated the neuroprotective effect of carvedilol in $\mathrm{SCl}$. In the present study, we investigated the neuroprotective effects of carvedilol after $\mathrm{SCl}$. MDA levels make up the most important indicator for lipid peroxidation (1). In our study, we used MDA levels for to determine the rate of lipid peroxidation. MDA levels were lower in the only laminectomy group than the trauma group. These results showed that carvedilol treatment was effective at reducing lipid peroxidation.

Reactive oxygen species have destructive effects on neuronal cells after $\mathrm{SCl}$. Antioxidant mechanisms play a valuable role in reversing these destructive effects. Reduced glutathione and SOD are endogenous antioxidants that neutralize the negative effects of free radicals. In our study, SOD and GSH levels were higher in the carvedilol treatment group than the trauma group. Our study showed that treatment with carvedilol reduced oxidative damage.

MPO is an enzyme located in azurophilic granules within neutrophils. Elevated MPO levels are seen in injured tissue because of neutrophil infiltration as an indicator of inflammation (5). We found that the highest level of MPO was seen in the trauma group and it was lower in the carvedilol treatment group. Based on these results, we can say that carvedilol may reduce inflammation in $\mathrm{SCl}$.
Reactive oxygen species cause neuronal damage by stimulating lipid peroxidation, DNA damage and neuronal apoptosis. Savitz et al. (2000) has previously shown the antiapoptotic effects of carvedilol in transient focal cerebral ischemia (11). In the present study, we showed increased apoptosis levels in SCl. Carvedilol reduced apoptotic cell counts in the traumatic spinal cord. Light microscopic examination showed neuronal and glial cell degeneration in the white and gray matter. In our study, degenerated neuronal cell and glial cell counts were lower in the carvedilol treatment group than the trauma group. However, we found that the normal glial and neuronal cell counts were higher in the carvedilol treatment group than the trauma group. These light microscopic findings showed that carvedilol reduced apoptosis and neuronal loss (Figure 5A-F).

Behavioral tests are used to determine the functional recovery after $\mathrm{SCl}$. In our study we used Tarlov's motor scale to evaluate the clinical outcome. We found that carvedilol provides improvement after $\mathrm{SCl}$. The functional recovery rate was statistically significant especially after the 24th hour of the $\mathrm{SCl}$ in the carvedilol treatment group.

In conclusion, the present study showed that carvedilol has neuroprotective effects after $\mathrm{SCl}$ and this is the first study that reveals the neuroprotective effect of carvedilol on neurobehavioral, biochemical and histopathological recovery after $\mathrm{SCl}$. Although this study has some limitations such as the number of rats, we believe that it may guide future studies.

\section{REFERENCES}

1. Bao F, Chen Y, Dekaban GA, Weaver LC: Early anti-inflammatory treatment reduces lipid peroxidation and protein nitration after spinal cord injury in rats. J Neurochem 88:1335-1344, 2004

2. Cheeseman $\mathrm{KH}$, Slatter TF: An introduction to free radical biochemistry. British Medical Bulletin 49:481-493, 1993

3. Draper $\mathrm{HH}$, Hadley $\mathrm{M}$ : Malondialdehyde determination as index of lipid peroxidation. Methods in Enzymology 186:421430,1990

4. Elman GL: Tissue sulfhydryl groups. Arch Biochem Biophys 82:70-77, 1959

5. Genovese T, Mazzon E, Crisafulli C, Di Paola R, Muiá C, Bramanti $P$, Cuzzocrea S: Immunomodulatory effects of etanercept in an experimental model of spinal cord injury. J Pharmacol Exp Ther 316:1006-1016, 2006

6. Hall ED: The neuroprotective pharmacology of methylprednisolone. J Neurosurg 76:13-22, 1992 
7. Hamada $Y$, Ikata T, Katoh S, Nakauchi K, Niwa M, Kawai $\mathrm{Y}$, Fukuzawa K: Involvement of an intracellular adhesion molecule 1-dependent pathway in the pathogenesis of secondary changes after spinal cord injury in rats. J Neurochem 66:1525-1531, 1996

8. Li M, Ona VO, Chen M, Kaul M, Tenneti L, Zhang X, Stieg PE, Lipton SA, Friedlander RM: Functional role and therapeutic implications of neuronal caspase- 1 and -3 in a mouse model of traumatic spinal cord injury. Neuroscience 99:333-342, 2000

9. Lysko PG, Lysko KA, Yue TL, Webb CL, Gu JL, Feuerstein G: Neuroprotective effects of carvedilol, a new antihypertensive agent, in cultured rat cerebellar neurons and in gerbil global brain ischemia. Stroke 23:1630-1636, 1992

10. Oettl K, Greilberger J, Zangger K, Hasilnger E, Reibnegger G, Jürgens $\mathrm{G}$ : Radical-scavenging and iron-chelating properties of carvedilol, an antihypertensive drug with antioxidative activity. Biochem Pharmacol 62:241-248, 2001

11. Savitz SI, Erhardt JA, Anthony JV, Gupta G, Li X, Barone FC: The novel beta-blocker, carvedilol, provides neuroprotection in transient focal stroke. J Cereb Blood Flow Metab 20:11971204,2000

12. Slemmer JE, Shacka JJ, Sweeney MI, Weber JT: Antioxidants and free radical scavengers for the treatment of stroke, traumatic brain injury and aging. Current Medicinal Chemistry $15: 404-414,2008$
13. Sun Y, Oberley LW, Li Y: A simple method for clinical assay of superoxide dismutase. Clin Chem 34:497-500, 1998

14. Tarlov IM, Klinger H: Spinal cord compression studies. AMA Arch Neurol Psychiatry 71:271-290, 1954

15. Tator $\mathrm{CH}$, Fehlings MG: Review of the secondary injury theory of acute spinal trauma with emphasis on vascular mechanisms. J Neurosurg 75:15-26, 1991

16. Yue TL, Cheng HY, Lysko PG, McKenna PJ, Feuerstein R, Gu JL, Lysko KA, Davis LL, Feuerstein G: Carvedilol, a new vasodilator and $\beta$-adrenergic blocking agents adrenoceptor antagonist, is an antioxidant and free radical scavenger. J Pharmacol Exp Ther 263:92-98, 1992

17. Yue TL, Lysko PG, Barone FC, Gu JL, Ruffolo RR, Feuerstein GZ: Carvedilol, a new antihypertensive drug with unique antioxidant activity: Potential role in cerebroprotection. Ann NY Acad Sci 738:230-242, 1994

18. Yue TL, Mckenna PJ, Gu JL, Cheng HY, Ruffolo Jr RR, Feuerstein GZ: Carvedilol, a new antihypertensive agent, prevents lipid peroxidation and oxidative injury to endothelial cells. Hypertension 22:922-928, 1993

19. Yue TL, Mckenna PJ, Lysko PG, Ruffolo Jr RR, Feuerstein GZ: Carvedilol, a new antihypertensive, prevents oxidation of human low density lipoprotein by macrophages and copper. Atherosclerosis 97:209-216, 1992 